\title{
Ethos Academic Scientific Community in Conditions of Openness*
}

\author{
Olga Savvina \\ Department of Ethics \\ Faculty of Humanities and Social Sciences \\ Peoples' Friendship University of Russia \\ Miklukho-Maklaya str., 10/2 \\ Moscow, Russia 117198 \\ E-mail: savvina-ov@rudn.ru
}

\author{
Vinera Mukhametzhanova \\ Department of Ethics \\ Faculty of Humanities and Social Sciences \\ Peoples' Friendship University of Russia \\ Miklukho-Maklaya str., 10/2 \\ Moscow, Russia 117198 \\ E-mail: mukhametzhanova-vs@rudn.ru
}

\begin{abstract}
The article deals with the moral norms of a modern academic scientist. In the first half of the 20th century, R. Merton brought forth the moral imperatives of a scientist in the field of Universalism, Communism, Disinterestedness, Organized scepticism, which, in spite of criticism, were practically the only system of a scientist's moral standards proposed by the sociology of science. In recent years, studies of the ethics of the scientific community have shown that $R$. Merton's moral standards are too idealistic for a scientist and do not work and are incompatible with the realities of the production of scientific knowledge in the world. In their article, the authors analyses the moral standards and anti-norms of the scientific community of the 20th century and the characteristic features of modern science-technology science. The study shows that $R$. Merton's norms did indeed have an impact within the academic ethos of science, but not the technological sciences where these norms have little influence. The authors conclude that it was precisely the norms of $R$. Merton that greatly contributed to the education of subsequent scientific manpower within the walls of the university and were an important moral guideline within the framework of the academic science. The article also analyses the conditions for the existence of modern universities, where competition is of a great importance. The authors concluded that these conditions do not contribute to the strengthening of these norms in the minds of academic scientists, which can subsequently adversely affect the development of scientific ethos in general.
\end{abstract}

Keywords-ethics of science; R. Merton; J. Ziman; university; Humboldt University model; sociology of science

\section{INTRODUCTION}

The question of particular interest to the ethics of science is the connected with the problem of the moral evaluation of cognitive activity as such [1]. So, in 1942 R. Merton characterized the ethos of the scientific community and derived four moral imperatives, which the scientific community follows [2]. In his work, he defines the ethos of science as: "The ethos of science is that affectively toned complex of values and norms which is held to be binding on

*The article was prepared with the financial support of the Russian Foundation for Basic Research, project 18-311-00063 mola "Moral imperatives in the work of a modern scientist". the man of science." Here are the imperatives that a scientist must adhere to if he wants to become part of the scientific community: Universalism, Communism, Disinterestedness, Organized skepticism (CUDOS) [2]. Subsequently, the norms of scientific ethos were supplemented by such qualities as lack of emotionality and rationality (lack of emotionality as means of achieving rationality), as well as a number of others, for example, originality and honesty [3], [4]. If a scientist follows all these principles, in particular, the principle of Communism, then all that's left in order to assert himself in the scientific community is to receive the recognition of the primacy of scientific discovery. Therefore, among scientists, especially academic ones, such great attention is paid to scientific publications. Every true scientist dreams of publishing his research in a prestigious journal and getting recognition from colleagues.

\section{THE CONCEPT OF ANTI-NORMS}

Further studies of sociologists in the field of the ethics of science have shown that not all scientists follow these norms, and sometimes on the contrary, in order to gain recognition in science, one must follow the anti-norm. A number of researchers of the second half of the twentieth century proposed a system of anti-norms, which should be adhered to if the scientist wishes to succeed in the scientific field [5], [6], [7]. I. Mitroff in 1974 published a paper [5], where he derived six anti-norms, opposed to the norms of R. Merton's system and subsequently supplemented by rationality and lack of emotion. In contrast to faith in rationality, he puts faith in rationality; lack of emotions - emotional involvement in the research process; universalism particularism (the priority of some, more eminent scientists over others); Communism-Miserism (distribution of ownership of the discovery, the need to keep the discovery a secret); Disinterestedness — interestedness; Organized skepticism - organized dogmatism (a scientist must believe in the truth of his own conclusions and doubt the conclusions of his colleagues). Responding to criticism I. Mitroff, R., Merton introduces the concept of the ambivalence of the ethos of science [4]. The norms indicated by him are an ideal, a reference point to which one should strive. Undoubtedly, the practice of scientific search is more complex than the 
theoretical model and sometimes the scientist has to adapt to circumstances, for example, be receptive to new revolutionary ideas, but at the same time not to succumb to scientific "fashion." J. Ziman wrote that Merton's norms are more relevant to the academic scientific community. The problem is that in the last decades' science often cooperates with business, state and industry [8]. This brings about significant changes in the realities of the "scientific cuisine" of scientists, who are forced to follow Ziman's principles of PLACE to get their PLACE on the career ladder [9]. The PLACE standards largely contradict the moral imperatives of Merton: Proprietary work is a work on the results of which a specific property right extends; Local work - work carried out to solve local problems and brings an adequate reward; Authoritarian work - work, determined by the authorities; Commissioned work; Expert work [4].

\section{THE CONCEPT OF TECHNOSCIENCE}

In parallel with the criticism of the Merton's system of moral imperatives in the philosophy of science, the concept of techno-science is being developed [10], [11]. According to B.G. Yudin in the second half of the twentieth and beginning of the 21 st century "the mechanisms of consumption of scientific and technical knowledge are radically transformed in society"[11]. A new type of relationship between science, technology and society was called technoscience. One of the main characteristics of technoscience is the in-depth scientific search in the creation and promotion of new technologies. Techno-science is more focused on the goals of the state, humanity and the needs of a particular consumer, not infrequently for profit, rather than for scientific search by itself and knowledge of the world. B.G. Yudin singles out the outer and inner contour of the techno-science [12]. The internal circuit is formed from laboratories, supplies to the laboratory, the characteristics of the work of scientists, equipment for experiments, patents for inventions of the laboratory and their design, as well as everything that is directly related to the production of new techno-scientific knowledge. The external contour of the technology is connected with the stakeholders of the scientific laboratory: these are commercial enterprises and industries interested in production, the state that makes an order for development, marketing departments of companies and marketing agencies that advertise and promote scientific developments. The external outline of science is directly related to the external, unscientific world, the world of human needs, social demands and state policy. Therefore, techno-science cannot help but be guided by the outside world, it constantly interacts with it.

\section{IV. "IVORY TOWER"}

In this regard, the science R. Merton wrote about, academic science differs in many ways from the technoscience. It was not rare when academic scientists in universities were called scientists from the "ivory tower" [13], which meant their remoteness from the world and its daily tasks and aspirations as well as a misunderstanding of life outside the university walls. Academic scholars did sometimes dive deep into their thoughts and theories, losing touch with the world, but this fact has its minuses and pluses. When I. Kant was writing about the superiority of the "lower" faculty — the philosophical, less connected with the practice and demands of the external world in comparison with the "highest" theological, legal and medical faculties, the main faculties of the Middle Ages and New Times, until the XIX century, he considered this isolation as a chance for objective truth [14]. Unrelated to any inquiry, the Faculty of Philosophy acquired the freedom of research necessary for the pursuit of truth. "Ivory Tower" thus becomes not only far from this world, where philosophers and scientists are free to play in their abstractions, but they thereby gain independence from this world, the independence of scientific and philosophical search. In this regard, academic scholars have an advantage over techno-scientists who are forced to constantly interact with the outside world and focus not on the truth (which the norms of the scientist R. Merton assume), but on demands from outside.

\section{V. VON HUMBOLdT MODEL AND ITS IMPORTANCE IN THE ACADEMIC ENVIRONMENT}

Nevertheless, the "ivory tower" of academic scientists began to lose their advantages in the second half of the twentieth century. Schopenhauer also drew attention to the fact that university careerists, in the framework of the new $\mathrm{V}$. Humboldt model of the 19th century, try to write articles not in order to share knowledge with the world, but in order to obtain a higher social status or higher wages [15]. This was one of the facts that encouraged the philosopher to say that more harm than good comes from the university philosophy (philosophy placed within the framework of the organization). The model of the university of the German statesman, model V. Von Humboldt, new for European countries in the 19th century, presupposed the principle of the unity of science and education, where the teacher must actively engage in the sciences in order to be able to teach in higher education [16]. It was the moment when an urgent needs to evaluate the scientific contribution of a scientist appeared, and in many respects this contribution was determined by his publications. Then there are scientific journals and publications, where it is customary to publish scientists' works. Then the ground was created for the introduction of the scientist's ratings (the h-index (Hirsh index)), the rating of scientific periodical publications, and subsequently the rating of scientific institutions and universities.

The model of the University of V. Humboldt allowed overcoming the crisis of universities and "shopping culture". The latter was expressed in the fact that the educational program did not change for decades or even centuries, and the science studies did not always attract university teachers, knowledge became stiff, lost relevance and fell behind scientific and technological progress for centuries [17]. Having revived the university, the Humboldt model introduced elements of competition into the life of academic scientists, placing their income in dependence on the results of their scientific research. Even in the Middle Ages, universities were divided into the most and less prestigious, but with the advent of the large-scale of higher education in 
the twentieth century, when more and more people wanted and had the opportunity to get higher education, the competition between universities seriously worsened. The Spanish scholar H. Ortega y Gasset even wrote about the need to change the mission of the university, focusing on integrating youth into the cultural space of modernity, and not on the scientific search for university scientists who are not always good teachers [18]. By the last decades of the twentieth century, the ratings of universities have become quite widespread, the prestige of universities and universities have rushed into competition for places in the ranking. B. Readings in his work The University in Ruins wrote about the pursuit of universities for "perfection", while at the verge of "perfection" was an empty concept. The competition of universities has become a competition for the place in the rating and the number of scientific publications in wellknown magazines, as well as ... the number of parking spaces in the university parking lot [18]. The latter indicator can also be a criterion for evaluating the university. Analysing these criteria, B. Readings repeatedly points to ridiculous indicators, such as academic reputation, which consists of a certain percentage of itself. [19].

\section{UNIVERSITY OF THE XXI CENTURY}

In the 21 st century a new demand for universities appeared: the principle of openness, according to which information about the university and its successes in the scientific field should be publicly accessible. The information that should be shown may include the number of scientific articles published by the university staff, the number of grants won, the technical equipment of laboratories, and information not related to scientific achievements: the availability of training in relevant specialties, the availability of places in dormitories and even staff salaries. To be open, universities must formalize their scientific search, the educational process, buildings and other components of university life, and express them in the generally accepted indicators mentioned above. Openness requires from universities some common denominators that are well understood by an outside observer. A complex system for evaluating universities is being formed: the figures represent all the components reflecting the life of the university, such as science, the academic process, extracurricular activities, etc. Universities now cannot not join the race for indicators, distracting employees from the true values of the university, striving for scientific truth, transferring knowledge to the next generation.

\section{CONCLUSION}

Thus, the advantages of the "ivory tower" are lost because of the competitive struggle the universities find themselves in. Academic scholars no longer have the independence of scientific research, of which Kant spoke. At the same time, they are more likely than scientists to work in transnational companies or government organizations to be separated from the outside world. In addition, people often try to bypass the system by fulfilling a plan upon indications, administrators are forced to change the incentive scheme, and this war takes a lot of effort, increases staff reporting and bureaucratic work, anti-norms described by Mitroff I.I., West S.S. come into play and S. Fuller. It turns out that the modern academic scientist is increasingly moving away from the moral imperatives of R. Merton, and at the same time he is far from the techno-science, which more closely cooperates with other institutions. It should also be noted that one of the requirements of openness and successful competition in the academic environment is interaction with state and commercial structures, which somehow brings academic scholars closer to the technology, but again delays the moral imperatives of R. Merton. One could say, following the critics of the Merton paradigm that it does not work, at least in modern society, but nevertheless it is the ideal of a truthseeking scientist (and finding public recognition due to his contribution to science) that continues to inspire many students and young scientists. These norms make it possible to grow a new generation of scientists and have a great educational potential. Few people want to engage in science all their lives only for the sake of money and social status, with these goals you can choose another occupation. Norms of R. Merton effectively worked within the walls of the university, partially detached from the world, but now this island is also in danger, and the search for scientific fundamental knowledge can be replaced by the pursuit of articles and indicators.

\section{REFERENCES}

[1] Mukhametzhanova V.S. Ethics of science and responsibility of scientist. RUDN Journal of Philosophy. 2018; 22 (3):304. doi: 10.22363/2313-2302-2018-22-3-301-309.P.304.

[2] Merton R. The Normative Structure of Science/ Panarchy. [URL: https://www.panarchy.org/merton/science.html] (Date of appeal: 19.09.2018).

[3] Lazar M. G. The Ethos of science in sociology R. Merton: the fate and status in the research on research// Sociology of science and technology. 2010. №4. [URL: https://cyberleninka.ru/article/n/etosnauki-v-sotsiologii-r-mertona-sudba-i-status-v-naukovedenii-1] (Date of appeal: 19.09.2018).

[4] Demina N. V. The concept of the Ethos of science: Merton and others in search of social geometry norms / / Sociological journal. 2005. №4. P.5-47.

[5] Mitroff I.I. The subjective side of science: A philosophical inquiry into the psychology of the Apollo Moon scientists. Amsterdam and San Francisco: Elsevier and Jossey-Bass, 1974.

[6] West S.S. The ideology of academic scientists // IRE Transactions on Engineering Management. 1960. Vol. EM-7. No. 2. P. 54-62.

[7] Fuller S. Science. Buckingham: Open University Press, 1997. Ch. 4.

[8] Ziman J. Real science: What it is, and What it means. Cambridge: CambridgeUniversityPress, 2000.

[9] Savvina O. V. The Research in the field of ethics of the scientific community and trends in its development // Philosophy and culture.2011. №5 (26).P. 148-154.

[10] Hottois G. Techno-sciences and ethics / Agazzi E. Right, Wrong and Science. Ed. by Craig Dilworth. Poznań Studies in the Philosophy of Science and Humanities, Vol. 81. Amsterdam-NY, 2004.

[11] Yudin B. G. Science in the knowledge society // Questions of philosophy.[URL:

http://vphil.ru/index.php?option=com_content\&task=view\&id=193\& Itemid=52] (Date of appeal: 03.09.2018г.).

[12] Yudin B. G. Technoscience and the «improvement of human» // Epistemology \& Philosophy of Science. 2016. №2 (48). [URL: https://cyberleninka.ru/article/n/tehnonauka-i-uluchshenie-cheloveka] (Date of appeal: 20.09.2018). 
[13] Sokolov M., Guba K., Zimenkova T., Safarova M., Chuikina S. how to become professors: academic careers, markets and power in five countries. - M.: New literary review, 2015.P. 158-160.

[14] Kant I. The Dispute of the faculties. [URL:http://kant-online.ru/wpcontent/uploads/2015/08/TSelikom.pdf] (Date of appeal: 20.09.2018).

[15] SchopenhauerA. About the University of philosophy/ International Theosophical society. [URL:http://www.theosophy.ru/lib/schop.htm] (Date of appeal: 03.09.18).

[16] Savvina O.V. Humboldt's university model in the contemporary world // Bulletin of PFUR, series «Philosophy». 2016. №3. P. 42-50.

[17] AndreevA. Russian Universities of the 18th - the first part of the 19th century in the context of university history in Europe. M., 2009. P. 265-285.

[18] Ortega y Gasset J. Mission of the University. Trans. by M.N. Golubeva. Ed. by M.A. Gusakovsky. Minsk, 2005.

[19] Readings B. The University in Ruins. Cambridge: Harvard University Press, 1997.P. 21-43. 